\title{
The prevalence of inhalant use and associated factors among adolescents in Belo Horizonte, Brazil
}

\author{
Prevalência do uso de inalantes e fatores associados \\ em adolescentes de Belo Horizonte, Brasil
}

Fernando Silva-Oliveira ${ }^{1}$

Kelly Oliva Jorge ${ }^{2}$

Efigênia Ferreira e Ferreira ${ }^{1}$

Míriam Pimenta Vale ${ }^{2}$

Ichiro Kawachi ${ }^{3}$

Patrícia Maria Zarzar ${ }^{2}$
${ }^{1}$ Departamento de Odontologia Social e Preventiva, Faculdade de Odontologia, Universidade Federal de Minas Gerais. Av. Antônio Carlos 6627, Pampulha. 31.270-901 Belo Horizonte MG Brasil. nando.sol@gmail.com ${ }^{2}$ Departamento de Odontopediatria e Ortodontia, Universidade Federal de Minas Gerais. ${ }^{3}$ Harvard School of Public Health.
Abstract The scope of this study was to establish the prevalence of inhalant use among adolescents and its association with marijuana use, alcohol consumption, socioeconomic status and gender. A cross-sectional study was performed with a representative sample of 891 adolescents from public and private schools in the city of Belo Horizonte, Brazil. Data were collected using two self-administered questionnaires: the Alcohol, Smoking and Substance Involvement Screening Test (ASSIST) and the Alcohol Use Disorders Identification Test (AUDIT C). The socioeconomic status was evaluated using the Social Vulnerability Index, mother's education level and type of school (public or private). The data were analyzed using the chisquare test $(p<0.05)$ and logistic regression analysis. The prevalence of inhalant use was $7.9 \%$. No significant association was found between the use of inhalants and socioeconomic status after the logistic regression analysis. Inhalant use among adolescents was associated with marijuana use (OR: 4.61; 95\% CI: 2.27 - 9.36) and with binge drinking (OR: 5.02; 95\% CI: 2.57 - 9.81). Key words Inhalants, Adolescents, Binge drinking, Illicit drugs, Socioeconomic factors, Epidemiology
Resumo O objetivo deste estudo foi avaliar a prevalência do uso de inalantes em adolescentes e sua associação com o uso de maconha, consumo de álcool, condição socioeconômica e gênero. Um estudo transversal foi realizado em uma amostra representativa de 891 adolescentes de escolas públicas e privadas de Belo Horizonte, Brasil. Os dados foram coletados por meio de dois questionários autoaplicáveis: o Alcohol, Smoking and Substance Involvement Screening Test (ASSIST) e o Alcohol Use Disorders Identification Test (AUDIT C). O Índice de Vulnerabilidade Social, o nível de escolaridade da mãe e o tipo de escola (pública ou privada) foram utilizados para determinar o nível socioeconômico. Os dados foram analisados utilizando o teste qui-quadrado $(p<0.05)$ e a análise de regressão logística. A prevalência do uso de inalantes foi de 7,9\%. Não houve associação entre o uso de inalantes e o nível socioeconômico após a análise de regressão logística. O uso de inalantes por adolescentes esteve associado ao uso de maconha (OR: 4.61; 95\% CI: 2.27 - 9.36) e ao consumo abusivo de álcool (OR: 5.02; 95\% CI: 2.57 - 9.81).

Palavras-chave Inalantes, Adolescentes, Beber pesado, Drogas ilícitas, Fatores socioeconômicos, Epidemiologia 


\section{Introduction}

According to the Diagnostic and Statistical Manual of Mental Disorders (DSM-IV), inhalant drugs are psychotropic substances divided into four groups based on their action mechanism: volatile solvents, aerosols, gases and nitrites ${ }^{1}$. Ethyl chloride (found in lança perfume - an etherbased drug used in Brazil), benzene derivatives (solvents found in some glues and paints), ether, benzene and chloroform are examples of common psychoactive inhalants.

Many of these substances are widely available, easily obtained and relatively inexpensive, which likely contributes to the high prevalence of use in the overall population ${ }^{2,3}$ and may also account for their popularity among adolescents $s^{4,5}$. Moreover, research suggests that first contact with drugs often occurs in adolescence, which is a period of significant physiological, social and psychological change and vulnerability ${ }^{6-8}$.

In 2005, researchers conducted a household survey in Brazil involving approximately 8000 individuals between 12 and 65 years of age in 108 cities with populations of more than 200,000 inhabitants. A total of $6.1 \%$ of the sample reported having used inhalants, which constituted the second most frequently consumed illicit drug after marijuana9. In surveys conducted by the Brazilian Information Center on Psychotropic Drugs (CEBRID) in 1987, 1989, 1993 and 1997 with representative samples of adolescents enrolled at elementary and high schools in ten Brazilian state capitals, inhalants had the highest reported use (over $13 \%$ of the samples) ${ }^{10}$. According to data from a survey conducted in 2010 by the US National Institute on Drug Abuse published in a report entitled "Monitoring the Future," 14.5\% of eighth grade students reported having used inhalants at least once, which was a higher usage rate than that reported for marijuana, amphetamines, hallucinogens, cocaine and heroin ${ }^{11,12}$.

Inhalants cause dependence ${ }^{13}$ and can lead to brain damage, heart problems, liver problems, kidney failure and death, including suicide ${ }^{5,13-17}$. These drugs can also contribute to personality, mood and anxiety disorders ${ }^{18-20}$ as well as broader social problems, such as violence and vandalism $^{15}$. Historically, alcohol, tobacco and marijuana have been considered the "gateway drug" of choice. This progression is followed by inhalants, which can lead to the use of harder substances, such as heroin and $\mathrm{crack}^{3}$. A number of studies also report the use of inhalants in combination with other drugs, especially marijuana, tobacco and alcohol ${ }^{3,20}$. This combined drug use needs to be investigated further to assist in the establishment of more effective public policies. Research also suggests that adolescents who use inhalants receive poorer grades at school and have higher scholastic failure, absenteeism and dropout rates $^{21,22}$.

This study was undertaken to identify groups that are more vulnerable to using psychoactive substances and multiple drugs, as such individuals are more susceptible to the combined use of inhalants and heavier drugs. Moreover, the identification of associated factors can help guide public policies regarding effective strategies aimed at inhibiting the use of inhalants and other drugs $^{3,22-24}$. Thus, the aim of the present study was to determine the prevalence of inhalant use among adolescents at public and private schools in the city of Belo Horizonte, Brazil, and investigate associations with marijuana use, alcohol consumption, socioeconomic status and gender.

\section{Methods}

\section{Study design and participants}

A cross-sectional study was carried out addressing lifetime inhalant use and its association with socioeconomic status, lifetime marijuana use and lifetime binge drinking among 936 adolescents aged 15 to 19 years enrolled at public and private schools in the city of Belo Horizonte between August 2009 and February 2010. Belo Horizonte is the state capital of Minas Gerais, Brazil. The city has approximately 2.4 million residents and is geographically divided into nine administrative districts ${ }^{25}$.

The sample was randomly selected using twostage stratified cluster sampling. The sample size was calculated to yield a standard error of $4.0 \%$. To ensure representativeness, the percentage distribution of students from 15 to 19 years was proportional to the actual distribution of students in the nine administrative districts of the city. One public and one private school were selected from each district. A 50\% prevalence rate of inhalant use was assumed for the calculation of the sample. The minimum sample size was estimated to be 600 individuals, to which $20 \%$ was added to compensate for possible losses ( $n$ $=720$ ). A correction factor of 1.3 was then applied to increase the precision, since multistage sampling was employed rather than random sampling, leading to a total of 936 adolescents. 
The proportion of refusals and losses resulting from incomplete questionnaires was $4.8 \%$ (45 adolescents) and the final sample comprised 891 adolescents.

\section{Survey}

A self-administered questionnaire was distributed in the classrooms by a researcher and assistant. To guard against bias that may occur due to the variability in reading proficiency among the students, the principal investigator (K.O.J.) read each question aloud. The students were told that the questionnaire would be anonymous and the responses would be treated confidentially. After completing the task, the students placed the questionnaires into opaque envelops, which were collected by the assistant. Students could refuse to participate and return incomplete questionnaires in the envelopes.

\section{Inhalants, marijuana and binge drinking}

Information on inhalant use, marijuana use and binge drinking was collected using two selfadministered questionnaires: the Alcohol, Smoking and Substance Involvement Screening Test (ASSIST) and the Alcohol Use Disorders Identification Test (AUDIT C), both of which have been validated for use in Brazil ${ }^{26,27}$.

The use of inhalants and marijuana was determined using the ASSIST (version 3.0). This measure was developed by the World Health Organization and an international research team of experts in the field of substance abuse who sought to create a simple method for mapping the use of psychoactive substances, such as alcohol, tobacco, marijuana, cocaine, crack cocaine, stimulants, hypnotics, sedatives, hallucinogens, opiates and inhalants. The questions address the frequency of lifetime use, use in the previous three months, problems related to substance use, concerns about use raised by individuals close to the user, impaired performance of tasks, unsuccessful attempts to cease or reduce use, sense of compulsion and use by injection. After answering the questionnaire, a risk score ranging from 0 to 4 is provided for each substance, which is then summed across all categories to yield a total score ranging from 0 to 20 . The scores are grouped as follows: 0 to 3 indicates occasional use; 4 to 15 implies substance abuse; and 16 or higher suggests dependence ${ }^{28}$.

For this study, the AUDIT C (first 3 questions of the AUDIT instrument related to the fre- quency and amount of alcohol consumed) was also used due to the fact that this measure can be effectively employed as a "stand-alone" screening measure to detect hazardous drinking among adolescents $\mathrm{s}^{28,29}$. Binge drinking was assessed with the question "How often do you have five or more drinks on one occasion?" The response options range from "never" to "daily." Binge drinking was used as the measure of alcohol use because this practice can result in more negative consequences than low to moderate amounts of drinking ${ }^{30}$.

\section{Socioeconomic status}

The Social Vulnerability Index (SVI) measures social exclusion in each neighborhood of the city of Belo Horizonte and was used in the present study as an indicator of socioeconomic status. The city hall database of SVI scores was used based on the address of each student ${ }^{31}$. This index has 20 variables grouped into five "dimensions of citizenship": (a) access to housing and basic infrastructure; (b) access to education; (c) access to income and employment; (d) access to legal assistance; and (e) access to health, food security and welfare ${ }^{30}$. Residential areas are categorized into five classes (Classes I to V). Class I indicates the highest degree of social vulnerability (poorest housing, schooling, income, jobs, legal assistance and health) and Class $\mathrm{V}$ indicates the lowest degree of social vulnerability (most advantageous conditions $)^{31}$.

Mother's education level (reported by the participants) was chosen as an indicator of individual socioeconomic status due to its association with illicit drug use among adolescents ${ }^{32}$. Respondents who reported that their mothers had studied for 0 to 7 years were coded as 0 and those who reported that their mothers had studied for 8 or more years were coded as 1 . The cutoff point was selected by the median.

The participant's type of school (public or private) was also used as a socioeconomic indicator. This variable has been used effectively in a large number of Brazilian epidemiological studies $^{32-35}$. Moreover, the authors of a recent study concluded that type of school is a useful socioeconomic indicator in studies involving children in Brazil ${ }^{36}$.

\section{Ethical considerations}

This study received approval from the $\mathrm{Hu}$ man Research Ethics Committee of the Universidade Federal de Minas Gerais (Brazil). Authori- 
zation to approach the students was obtained from the directors of the selected schools. The participants and their parents/guardians signed a statement of informed consent. The participants were assured anonymity and confidentially in their answers.

\section{Statistical analysis}

Data analysis was performed using the Statistical Package for Social Sciences (SPSS for Windows, v. 17.0, SPSS Inc., Chicago, IL, USA). Descriptive and bivariate analyses were performed using the chi-square test $(p<0.05)$. Logistic regression was used in the multivariate analysis. The criterion for inclusion in the model was a $p$-value $<0.20$ in the outcome of the bivariate analysis.

\section{Results}

The response rate was $98.5 \%$. Non-responses were mainly due to refusals on the part of the adolescents or non-authorization from parents/ guardians. The final sample was made up of 891 adolescents [ 352 males (39.5\%) and 539 females $(60.5 \%)$ ], with a mean age of $16.3 \pm 1.0$ years. A total of $80.5 \%$ attended public schools and $19.5 \%$ attended private schools. Seventy adolescents $(7.9 \%)$ reported lifetime inhalant use and 30 (3.9\%) reported having used this drug in the previous three months. Regarding the ASSIST scores for inhalant use, $99.1 \%(n=883)$ of the participants were in the low risk range ( 0 to 3 points) for health and other problems stemming from the current pattern of use and $0.8 \%(n=7)$ were in the moderate risk range ( 4 to 15 points).

Table 1 shows the distribution of the sample according to the prevalence of lifetime inhalant use and the independent variables. Lifetime inhalant use was associated with type of school ( $p$ $=0.001)$, mother's education level $(p=0.023)$, less socially vulnerable residential area based on the SVI $(p<0.001)$, lifetime marijuana use ( $p<$ $0.001)$ and lifetime binge drinking $(p<0.001)$.

Table 2 displays the results of the logistic regression analysis. After adjusting for age, gender, type of school, mother's education level and SVI, adolescents who reported lifetime inhalant use had increased odds of lifetime binge drinking (adjusted OR: 5.02 ; 95\% CI: 2.57 to 9.81 ) and lifetime marijuana use (adjusted OR: 4.61; 95\% CI: 2.27 to 9.36$)$.

\section{Discussion}

The prevalence of inhalant use among adolescents enrolled at public and private schools in the city of Belo Horizonte (Brazil) was 7.9\%. The use of inhalants was positively associated with marijuana use and binge drinking in the multivariate regression model. A national household survey involving adolescents aged 12 to 17 years reports a $3.4 \%$ prevalence rate of inhalant use, with a higher rate among individuals aged 18 to 24 years (10.8\%). ${ }^{9}$ However, the study cited did not specify in detail how the collection process was carried out. Moreover, due to the fact that the investigation was a household survey, the prevalence of drug use among adolescents may have been somewhat underestimated. For instance, if the parent/guardian of an adolescent between 12 and 17 years of age was at home at the time of the interview, the respondent may have been more reluctant to respond honestly. Moreover, a household survey may be considered less impersonal and the findings may therefore seem less confidential, leading an adolescent to fear that the researcher could inform his/her parents/guardians regarding the use of illicit drugs.

A number of studies published in the literature report higher prevalence rates of inhalant use among Brazilian adolescents. In a study conducted in 10 major cities in Brazil ${ }^{10}$, the authors report that $13.8 \%$ of the sample population had used inhalants, including a $9 \%$ prevalence rate in the city of São Carlos ${ }^{6}$, which is close to the figure found in the present study (7.9\%). Much higher prevalence rates of inhalant use were also found in studies conducted in the cities of Florianópolis $(18.2 \%)^{37}$ and Palhoça $(18.9 \%)^{38}$. The high prevalence of inhalant use among adolescents may be explained by the wide availability of these substances, which are relatively inexpensive and of easy access ${ }^{2-5}$. Moreover, adolescence is a stage when an individual may be psychologically and socially more vulnerable and more susceptible to experimentation, since there is a need for approval and self-affirmation. Indeed, the first contact with psychotropic substances commonly occurs in this stage of life $e^{6-8}$.

Studies in the international literature reveal prevalence rates of inhalant use similar to that found in the present investigation. In a survey conducted in Peru with nationally representative data, the authors report inhalant use among 6.1\% of adolescents enrolled in schools around the country, listing inhalants among the most prevalent illicit drugs, along with marijuana ${ }^{39}$. A simi- 
Table 1. Distribution of the sample based on the prevalence of lifetime inhalant use and independents variables: Belo Horizonte, Minas Gerais, Brasil, 2011.

\begin{tabular}{|c|c|c|c|c|}
\hline \multirow[b]{2}{*}{ Independents variables } & \multirow[b]{2}{*}{$\begin{array}{l}\text { Frequency } \\
\text { n (\%) }\end{array}$} & \multicolumn{2}{|c|}{ Lifetime inhalant use } & \multirow[b]{2}{*}{ p-value } \\
\hline & & $\begin{array}{c}\text { Yes } \\
\mathbf{n}(\%)\end{array}$ & $\begin{array}{c}\text { No } \\
\text { n }(\%)\end{array}$ & \\
\hline Gender & & & & 0.499 \\
\hline Male & $352(39.5)$ & $25(7.1)$ & $327(92.9)$ & \\
\hline Female & $539(60.5)$ & $45(8.3)$ & $494(91.7)$ & \\
\hline Age (dicothomized by median) & & & & 0.911 \\
\hline 15 to 16 & $529(59.4)$ & $42(7.9)$ & $487(92.1)$ & \\
\hline 17 to 19 & $362(40.6)$ & $28(7.7)$ & $334(92.3)$ & \\
\hline School & & & & 0.001 \\
\hline Public & $717(80.5)$ & $46(6.4)$ & $671(93.6)$ & \\
\hline Private & $174(19.5)$ & $25(13.8)$ & $150(86.2)$ & \\
\hline $\begin{array}{l}\text { Mother's school level (number of } \\
\text { years of schooling) }\end{array}$ & & & & 0.023 \\
\hline 0 to 7 & $306(42.3)$ & $17(5.6)$ & $289(94.4)$ & \\
\hline 8 or more & $418(57.7)$ & $43(10.3)$ & $375(89.7)$ & \\
\hline Social Vulnerability Index (SVI) ${ }^{* *}$ & & & & $<0.001$ \\
\hline Class I & $125(14.0)$ & $7(5.6)$ & $118(94.4)$ & \\
\hline Class II & $353(39.6)$ & $15(4.2)$ & $338(95.8)$ & \\
\hline Class III & $195(21.9)$ & $21(10.8)$ & $174(89.2)$ & \\
\hline Class IV & $111(12.5)$ & $15(13.5)$ & $96(85.5)$ & \\
\hline Class V & $107(12.0)$ & $11(11.2)$ & $95(88.8)$ & \\
\hline Lifetime marijuana use & & & & $<0.001$ \\
\hline Yes & $66(7.4)$ & $22(33.3)$ & $44(66.7)$ & \\
\hline No & $825(92.6)$ & $48(5.8)$ & $777(94.2)$ & \\
\hline $\begin{array}{l}\text { Binge drinking ( } 5 \text { doses or more } \\
\text { on one occasion) }\end{array}$ & & & & $<0.001$ \\
\hline Yes & $321(36.0)$ & $57(18.8)$ & $264(82.2)$ & \\
\hline No & $570(64.0)$ & $13(2.3)$ & $557(97.7)$ & \\
\hline
\end{tabular}

* Qui-Square test. ${ }^{* *}$ Class I and II are residential areas that denote the worst community conditions or great vulnerability to a social exclusion, while class IV and V are residential areas that denote best community conditions.

lar study conducted in Chile in 2009 reports inhalant use among an estimated $8.9 \%$ of the adolescent population ${ }^{40}$. In the United States, the latest "Monitoring the Future" report indicates a prevalence rate of $14.5 \%$ among eighth graders and $12 \%$ among tenth graders ${ }^{11}$.

The use of illicit drugs has been largely associated with the male gender ${ }^{21}$. However, the same is not true for inhalants, for which prevalence rates are often similar between males and females ${ }^{38,39}$. In the present study, no statistically significant difference in the use of inhalants was found between genders among the individuals who reported drug use at some point in life $(7.1 \%$ for males and $8.3 \%$ for females). Studies carried out in Peru and Chile also report no significant difference in the prevalence of substance abuse between genders ${ }^{39,40}$. However, a study carried out in Spain found that males were two times more likely to abuse drugs than females (3.6\% vs. $1.8 \%$, respectively $)^{41}$. Likewise, a household survey in Brazil reports figures of $10.3 \%$ for males and 3.3\% for females 9 . In contrast, the US report "Measuring the Future" found a higher prevalence rate of substance abuse among girls aged eight and ten years (16.3\% and $12.2 \%$, respectively) in comparison to males of the same age $(12.4 \%$ and $10.9 \%$, respectively $)^{11}$. This report has been published annually since 1975 and the data show a progressive increase in drug use among females, even surpassing that of males in some cases. ${ }^{11}$ Two hypotheses may be put forth to explain these findings: 1) it may be that females have their first contact with drugs earlier than males ${ }^{22}$ or 2) the greater independence obtained by women in recent decades may have led to an increase in the use of psychotropic substances among females ${ }^{22}$. In the health field, the female gender as a social 
Table 2. Logistic regression for lifetime inhalant use and associated factors among adolescents $(\mathrm{n}=891)$, Belo Horizonte, Minas Gerais, Brasil, 2011.

\begin{tabular}{|c|c|c|}
\hline \multirow[b]{2}{*}{ Independent variables } & \multirow{2}{*}{ Crude OR 95\% CI } & \multirow{2}{*}{$\frac{\text { inhalant use }}{\text { Adjusted OR } 95 \% \mathrm{CI}^{* *}}$} \\
\hline & & \\
\hline \multicolumn{3}{|l|}{ Age } \\
\hline 15 to 16 & 1.0 & 1.0 \\
\hline 17 to 19 & $0.97(0.59-1.60)$ & $1.43(0.76-2.67)$ \\
\hline \multicolumn{3}{|l|}{ Gender } \\
\hline Male & 1.0 & 1.0 \\
\hline Female & $1.19(0.71-1.98)$ & $1.15(0.64-2.11)$ \\
\hline \multicolumn{3}{|l|}{ Type of school } \\
\hline Public & 1.0 & 1.0 \\
\hline Private & $2.33(1.38-3.94)$ & $1.67(0.78-3.56)$ \\
\hline \multicolumn{3}{|l|}{ Mother educational background } \\
\hline$\leq 7$ years & 1.0 & 1.0 \\
\hline$\geq 8$ years & $1.95(1.09-3.49)$ & $0.97(0.46-2.04)$ \\
\hline \multicolumn{3}{|l|}{ SVI (Socio vulnerability Index)* } \\
\hline Class I & 1.0 & 1.0 \\
\hline Class II & $0.45(0.30-1.88)$ & $0.1(0.19-1.92)$ \\
\hline Class III & $2.03(0.83-4.94)$ & $1.57(0.51-4.86)$ \\
\hline Class IV & $2.63(1.03-6.72)$ & $1.70(0.50-5.79)$ \\
\hline Class IV & $2.13(0.80-5.62)$ & $0.99(0.25-3.89)$ \\
\hline \multicolumn{3}{|l|}{ Lifetime marijuana use } \\
\hline No & 1.0 & 1.0 \\
\hline Yes & $8.09(4.49-14.59)$ & $4.61(2.27-9.36)$ \\
\hline \multicolumn{3}{|c|}{ Binge drinking ( 5 doses in one occasion) } \\
\hline No & 1.0 & 1.0 \\
\hline Yes & $9.25(4.98-17.20)$ & $5.02(2.57-9.81)$ \\
\hline
\end{tabular}

"Class I and II are residential areas that denote the worst community conditions or great vulnerability to a social exclusion, while class IV and V are residential areas that denote best community conditions. ${ }^{* *}$ Adjusted for age, sex, type of school, mother's education and Social Vulnerability Index (SVI).

group may require more attention in substance abuse studies due to the noted expansion of consumption indices and the problems arising from the use of psychoactive substances in this population ${ }^{42}$. However, it should be stressed that prevalence studies split along gender lines only offer a descriptive analysis for the use of inhalants. Moreover, no statistically significance associated was found between illicit drug use and gender in a study involving adolescents in Pelotas, Brazil, as the prevalence was $14.6 \%$ among males and $13.9 \%$ among females ${ }^{21}$.

To debunk another myth, many also believe that drugs are more commonly used among individuals belonging to lower social strata. However, the literature provides conflicting findings on this issue. While some studies positively link drug use to a lower socioeconomic status ${ }^{7}$, others report a positive correlation with a higher status $^{21}$. In the present study, no statistically significant association was found between the use of inhalants and socioeconomic factors in the multivariate analysis. There is a certain difficulty in comparing studies that investigate the association between drug use and socioeconomic factors due to the lack of standardization regarding the analysis of socioeconomic status ${ }^{43}$. Some studies use indirect indicators of socioeconomic status, such as parental education level, place of residence, household income and type of school ${ }^{6,21,44}$. As a result, there is no consensus on the association between the use of inhalants and socioeconomic status ${ }^{9,22,33-36}$. Further studies on this association are needed.

Alcohol, cigarettes and marijuana have historically been regarded gateway drugs ${ }^{3,45,46}$. Scientific evidence shows a progression from these early stage gateway drugs to a more advanced stage, which may involve heavier drugs, such as cocaine, heroin and crack, or multiple drug use $\mathrm{e}^{3,44-}$ ${ }^{46}$. As mentioned above, first contact with gateway drugs often occurs in adolescence and there 
is no basis on which to establish the position of inhalant substances in the progression of drug use $^{3,6}$. However, Ding et al. ${ }^{3}$ demonstrated that smoking initiation followed by the consumption of alcohol, marijuana and inhalants is a common progression. Moreover, a number of studies report the combined use of inhalants with other drugs, particularly alcohol, cigarettes and marijuana ${ }^{3,20,47-49}$, as reported in the present investigation. The findings of these studies demonstrate that inhalant use does not generally occur in an isolated fashion. Indeed, individuals who report having used inhalants some time in life have generally also used other substances and there is a strong association between the use of inhalants and cigarettes, alcohol and marijua$\mathrm{na}^{3,47,50}$, as reported for a sample involving 12year-olds in the United States. ${ }^{3}$ According to data from a study by Carlini-Marlatt et al. ${ }^{47}$, high school students who report using alcohol and those who report having engaged in binge drinking had an increased risk of using inhalants (OR: 2.20; 95\% CI: 1.13 - 4.27 and OR: 2.70 ; 95\% CI: $1.27-5.74$ respectively). The present data are in agreement with these findings, since the inhalant use was associated with marijuana use (OR: 4.61; 95\% CI: $2.27-9.36$ ) and binge drinking (OR: 5.02; 95\% CI: 2.57 - 9.81).

Few studies in the literature describe the harmful effects of inhalant drugs. Associations are reported between the use of psychotropic drugs (including inhalants) and school absenteeism, scholastic failure and dropout rates among adolescents $^{21,22}$. These substances are also associated with mental problems, such as personality, mood and anxiety disorders ${ }^{18,19}$, as well as social problems (violence and vandalism) ${ }^{14}$. Inhalant drugs can cause addiction ${ }^{13}$ and physical harm, such as brain damage, liver failure and kidney failure $e^{5,13-17}$. Along this same line, studies have reported increased prevalence rates of psy- chiatric disorders among individuals who abuse substances such as marijuana, alcohol, cigarettes and inhalants ${ }^{17,18,51}$. There is also evidence of a greater risk of death and suicide among users of psychoactive drugs ${ }^{5,17,51}$. The combined use of psychoactive drugs is potentially the most harmful. It is therefore important to investigate this aspect further and offer data that can contribute to more coherent preventive measures.

The present study has limitations that should be addressed. Although the data collection was performed with self-reported questionnaires and the assurance of anonymity and confidentiality in the responses, the actual use of inhalants among the students could have been under-reported or even exaggerated. Moreover, the study only involved adolescents enrolled in schools and those who had dropped out were therefore not included. This is a particular problem, since research indicates a higher prevalence rate of the inhalant use among dropouts ${ }^{15}$. As described in the methodology, this study was a cross-sectional investigation, which does not allow the establishment of causality among the variables ${ }^{52}$. Therefore, the authors cannot state with absolute confidence that the use of inhalants was the cause of marijuana use or binge drinking or vice-versa. However, inhalant use was associated with marijuana use and binge drinking, as clearly demonstrated in the logistic regression following the necessary adjustments made for confounding factors. Moreover, longitudinal or experimental studies are needed to test the causality between drug use and socioeconomic status ${ }^{52}$.

The findings of the present study demonstrate that preventive public policies should be strengthened and focused on adolescents, considering the high prevalence rate of inhalant use in this group ${ }^{3,6,9-11,21,37-40}$. Moreover, the associations with marijuana use and binge drinking demonstrate the need to address multiple drug use. 


\section{Collaborations}

KO Jorge, EF Ferreira and PM Zarzar conceptualized the study. KO Jorge collected the data. F Silva-Oliveira drafted the first version. PM Zarzar conducted the analysis. I Kawachi and PM Zarzar contributed substantially to the interpretation of the findings. KO Jorge, EF Ferreira, MP Vale and PM Zarzar revised the manuscript for important intellectual content. All authors read and approved the final version of the manuscript.

\section{Acknowledgments}

The authors would like to thank the Brazilian fostering agency FAPEMIG for its generous support.

\section{Referências}

1. American Psychiatric Association. Diagnostic and statistical manual of mental disorders. $4^{\text {th }}$ Edition. Text revision (DSM IV TR). Washington: American Psychiatric Association; 2000.

2. Ridenour TA. Inhalants: not to be taken lightly anymore. Curr Opin Psychiatry 2005; 18(3):243-247.

3. Ding K, Chang GA, Southerland R. Age of inhalant first time use and its association to the use of other drugs. J. Drug Education 2009; 39(3):261-272.

4. Carlini EA, Galduróz JCF, Noto AR, Nappo SA. I Levantamento Domiciliar Nacional sobre o uso de drogas psicotrópicas no Brasil - 2001. São Paulo: Centro Brasileiro de Informações sobre Drogas Psicotrópicas (CEBRID); 2002.

5. Freedenthal S, Vaughn MG, Jenson JM, Howard MO. Inhalant use and suicidality among incarcerated youth. Drug Alcohol Depend 2007; 90(1):81-88.

6. Pratta EMM, Santos MA. Adolescência e uso de substâncias psicoativas: o impacto do nível. Rev Latino-am Enfermagem 2007; 15(Special Issue):806811.

7. Schenker M, Minayo MCS. Fatores de risco e de proteção para o uso de drogas na adolescência. Cien Saude Colet 2005; 10(3):707-717.

8. Rebolledo EA, Medina NMO, Pillon SC. Factores de riesgo asociados al uso de drogas em estudiantes adolescentes. Rev Latino-am Enfermagem 2004; 12(Special Issue):369-375.

9. Brasil. Secretaria Nacional de Política sobre Drogas. Relatório brasileiro sobre drogas. Brasília: Presidência da República Federativa do Brasil; 2009.

10. Galduróz JCF, AR, Fonseca AM, Carlini EA. Trends in drug use among students in Brazil: analysis of four surveys in 1987, 1989, 1993 and 1997. Braz J Med Biol Res 2004; 37(4):523-531.

11. Johnson LD, O'Malley PM, Bachman JG, Schulenberg JE. Monitoring the future: national survey results on drug use, 1975 - 2006. Bethesda: National Institute on Drug Abuse; 2007.

12. Johnson LD, O’Malley PM, Bachman JG, Schulenberg JE. Monitoring the future: national survey results on drug use, 1975 - 2010. Bethesda: National Institute on Drug Abuse; 2011.

13. Perron BE, Howard MO. Adolescent inhalant use, abuse and dependence. Addiction 2009; 104(7):11851192.

14. Ridenour TA. Inhalants: not to be taken lightly anymore. Curr Opin Psychiatry 2005; 18(3):243-247.

15. Garland EL, Howard MO. Adverse consequences of acute inhalant intoxication. Exp Clin Psychopharmacol 2011; 19(2):134-144.

16. Anderson CE, Loomis GA. Recognition and prevention of inhalant abuse. Am Fam Physician 2003; 68(5):869-874.

17. Howard MO, Perron BE, Sacco P, Ilgen M, Vaughn MG, Garland E, Freedentahl S. Suicide ideation and attempts among inhalant users: results from the national epidemiologic survey on alcohol and related conditions. Suicide Life Threat Behav 2010; 40(3):276-286. 
18. Wu LT, Howard MO. Psychiatric disorders in inhalant users: results from The National Epidemiologic Survey on Alcohol and Related Conditions. Drug Alcohol Depend 2007; 88(2-3):146-155.

19. Wu LT, Howard MO, Pilowsky DJ. Substance use disorders among inhalant users: Results from the National Epidemiologic Survey on Alcohol and Related Conditions. Addict Behav 2008; 33(7):968-973.

20. Johnson EO, Schiitzb CG, Anthonya JC, Ensminger ME. Inhalants to heroin: a prospective analysis from adolescence to adulthood. Drug Alcohol Depend 1995; 40(2):159-164.

21. Tavares BF, Béria JU, Lima MS. Prevalência do uso de drogas e desempenho escolar entre adolescentes. Rev Saude Publica 2001; 35(2):150-158.

22. Horta RL, Horta BL, Pinheiro RT, Morales B, Strey MN. Tabaco, álcool e outras drogas entre adolescentes em Pelotas, Rio Grande do Sul, Brasil: uma perspectiva de gênero. Cad Saude Publica 2007; 23(4):775-783.

23. Uchtenhagen A. How effective is substance abuse prevention? World Psychiatry 2005; 4(1):33.

24. Selby P, Vaccarino F. Substance abuse prevention: practical strategies for psychiatrists in the 21st century. World Psychiatry 2005; 4(1):32-33.

25. Brazilian Institute of Geography and Statistics (IBGE). Brazilian population recensus and estimative. [Internet]. Brasilia: IBGE. [cited 2012 Jun 10] Available from: http://www.ibge.gov.br/home/estatistica/ populacao/contagem

26. Henrique IFS, Micheli D, Lacerda RB, Formigoni MLOS. Validação da versão brasileira do teste de triagem do envolvimento com álcool, cigarro e outras substâncias (ASSIST). Rev Assoc Med Bras 2004; 50(2):199-206.

27. Lima CT, Freire AC, Silva AP, Teixeira RM, Farrell $\mathrm{M}$, Prince M. Concurrent and construct validity of the audit in an urban Brazilian sample. Alcohol 2005; 40(6):584-589.

28. Reinert DF, Allen JP. The alcohol use disorders identification test: an update of research findings. Alcohol Clin Exp Res 2007; 31(2):185-199.

29. Chung T, Colby S, Barnett N, Rohsenow D, Spirito A, Monti P. Screening adolescents for problem drinking: performance of brief screens against DSM-IV alcohol diagnoses. J Stud Alcohol 2000; 61(4):579587.

30. Courtney K, Polich, J. Binge drinking in young adults: data, definitions, and determinants. Psychol Bull 2009; 135(1):142-156.

31. Nahas MI, Ribeiro C, Esteves O, Moscovitch S, Martins VL. O mapa da exclusão social de Belo Horizonte: metodologia de construção de um instrumento de gestão urbana. Cad Cienc Soc 2000; 7(10):75-88.

32. Humensky JL. Are adolescents with high socioeconomic status more likely to engage in alcohol and illicit drug use in early adulthood? Subst Abuse Treat Prev Policy 2010; 5(1):19-29.
33. Moreira PVL, Rosenblatt A, Passos IA. Prevalência de cárie em adolescentes de escolas públicas e privadas na cidade de João Pessoa, Paraíba, Brasil. Cien Saude Colet 2007; 12(5):1229-1236.

34. Hoffman RHS, Cypriano S, Sousa MLR, Wada RS. Experiência de cárie dentária em crianças de escolas públicas e privadas de um município com água fluoretada. Cad Saude Publica 2004; 20(2):522-528.

35. Maltz M, Barbachan e Silva B. Relação entre cárie, gengivite e fluorose e nível socioeconômico em escolares. Rev Saude Publica 2001; 35(2):170-176.

36. Piovesan C, Pádua MC, Ardenghi TM, Mendes FM, Bonini GC. Can type of school be used as an alternative indicator of socioeconomic status in dental caries studies? A cross-sectional study. BMC Med Research Methodol 2011; 11(1):37-43.

37. Baus J, Kupek E, Pires M. Prevalência e fatores de risco relacionados ao uso de drogas entre escolares. Rev Saude Publica 2002; 36(1):40-46.

38. Sanceverino SL, Abreu JLC. Aspectos Epidemiológicos do uso de drogas entre estudantes do ensino médio no Município de Palhoça 2003. Cien Saude Colet 2004; 9(4):1047-1056.

39. Perú. Comisión Nacional para el Desarrollo y Vida sin Drogas. Estudio nacional. Prevención y consumo de drogas en estudiantes de secundaria 2005. Lima: Comisión Nacional para El Desarrollo y Vida sin Drogas; 2006.

40. Chile. Consejo Nacional para el Control del Estupefacientes (CONACE). Octavo estudio nacional de drogas en población escolar de Chile. Santiago: Consejo Nacional para el Control del Estupefacientes; 2009.

41. España. Delegación del Gobierno para el Plan Nacional Sobre Drogas. Encuesta estatal sobre uso de drogas em Estudiantes de enseñanzas secundarias, 1994-2008. Madrid: Delegación del Gobierno para el Plan Nacional Sobre Drogas; 2009.

42. Costa-e-Silva VL, Koifman S. Smoking in Latin America: a major public health problem. Cad Saude Publica 1998; 14(3):99-108.

43. Kandel DB, Yamaguchi K, Chan K. Stages of progression in drug involvement from adolescence to adulthood: Further evidence for the gateway theory. J Stud Alcohol 1992; 53(5):447-457.

44. Blaze-Temple D, Lo SK. Stages of drug use: A community survey of Perth teenagers. Br J Addict 1992; 87(2):215-225.

45. Chen X, Unger JB, Cruz TB, Johnson CA. Smoking patterns of Asian- American youth in California and their relationship with acculturation. $J$ Adolesc Health 1999; 24(5):321-328.

46. Kandel DB, Yamaguchi K. Stages and pathways of drug involvement: Examining the Gateway hypothesis. New York: Cambridge University Press; 2002.

47. Carlini-Marlatt B, Gazal-Carvalho C, Gouveia N, Souza MFM. Drinking practices and other healthrelated behaviors among adolescents of Sao Paulo City, Brazil. Subst Use Misuse 2003; 38(7):905-932. 
48. Isralowitz R, Reznik A. Ethnicity and inhalant use among high risk adolescents in Israel. J Ethn Subst Abuse. 2012; 11(2):192-196.

49. Driscoll DL, Dotterrer B, Collins D, Ogilvie K, Grube J, Johnson K. Demographic and contextual factors associated with inhalant use among youth in rural Alaska. Int J Circumpolar Health 2012; 71:1-4.

50. Reid LW, Elifson KW, Sterk CE. Ecstasy and gateway drugs: Initiating the use of ecstasy and other drugs. Ann Epidemiol 2007; 17(1):74-80.

51. Garland EL, Howard MO. Adverse consequences of acute inhalant intoxication. Exp Clin Psychopharmacol 2011; 19(2):134-144.

52. Kawashi I, Subramanian SV, Almeida-Filho N. A glossary for health inequalities. J Epidemiol Community Health 2002; 56(9):647-652.

Artigo apresentado em 22/05/2013

Aprovado em 15/09/2013

Versão final apresentada em 25/09/2013 